\title{
Chapter 3 \\ Major Water Engineering Projects: \\ Definitions, Framework Conditions, Systemic Effects
}

\author{
Sebastian Hoechstetter, Christine Bismuth, and Hans-Georg Frede
}

\begin{abstract}
This chapter aims at providing an overview of major water engineering projects as they are perceived within the scope of this volume. Furthermore, general principles of water technologies and their role in water conflicts and for solving water-related problems are outlined. An evaluation framework of technological measures for water management is meant to serve as a guiding concept for the indepth analysis of the two study regions dealt with in this volume, i.e. the Fergana Valley and the Lower Jordan Valley.
\end{abstract}

Keywords Water technology $\bullet$ Definition of MWEPs $\bullet$ Trends in water engineering - Path dependency $\bullet$ Evaluation framework $\bullet$ Water storage • Water distribution • Water use $\bullet$ Integrated water resource management $\bullet$ Water engineering

\footnotetext{
S. Hoechstetter $(\square)$

Helmholtz Centre Potsdam - GFZ German Research Centre for Geosciences, Telegrafenberg, 14473 Potsdam, Germany

e-mail: sebastian.hoechstetter@gmx.de

C. Bismuth

Interdisciplinary Research Group Society - Water - Technology,

Berlin-Brandenburg Academy of Sciences and Humanities,

Jägerstraße 22/23, 10117 Berlin, Germany

Helmholtz Centre Potsdam - GFZ German Research Centre for Geosciences, Telegrafenberg, 14473 Potsdam, Germany

H.-G. Frede Institute of Landscape Ecology and Resource Management (ILR), Justus-Liebig-Universität Gießen, Heinrich-Buff-Ring 26-32, 35392 Gießen, Germany 


\subsection{Definition of Major Water Engineering Projects - A Proposal}

Major water engineering projects (MWEPs) have been the subject of a large number of studies and analyses in a variety of scientific disciplines. However, a precise, standardised and generally accepted definition is missing so far.

Thinking of MWEPs, one of the first associations coming to the mind of many people might be large dams and reservoirs. A rather simple definition of large dams has been provided by ICOLD (International Commission on Large Dams). ICOLD has defined them as dams with a height over $15 \mathrm{~m}$. Other institutions (such as the World Commission on Dams) additionally designate dams as "large" when they have a height between 5 and $15 \mathrm{~m}$ and a reservoir capacity of more than $3 \times 10^{6} \mathrm{~m}^{3}$. Similar specifications, however, are not available for other MWEPs.

Large-scale technological approaches, however, are not limited to dams and reservoirs, but also comprise irrigation management, industrial usage and many other purposes. Therefore, an attempt to a general definition of MWEPs is made in this chapter. We argue that the planning, implementation and evaluation of such projects should not be reduced to merely technical aspects. Instead, a more generic approach is pursued here, and the implications of MWEPs for economy, society and the environment are considered as well.

"Water engineering" has been defined by Lotti (1980) as the subject that includes (among others) "everything connected with the use of water resources, namely: the study of the element 'water' (hydrology and hydraulics); the definition of its uses and the structures needed for these; flood control; the maintenance of water quality standards; socioeconomic aspects; and the relationship between water resources and the environment."

Accordingly, within the scope of this volume, major water engineering projects are regarded as technical operations and construction schemes related to these fields with a spatial, temporal and economic extent that is likely to result in relevant and far-reaching effects on society and the environment. Their specific characteristics affect many sectors of public life. The most prominent feature of MWEPs, however, is their significant effect on and their (usually permanent) intervention into natural hydrological regimes.

The most important purposes of MWEPs relate to the following types usage (according to Lotti 1980):

- Water supply

- Irrigation

- Industrial use

- Energy production, conversion and storage

- Inland navigation

- Fishing

- Recreation

As a result, major water engineering projects feature both potentially beneficial and adverse outcomes and can be described by the following common characteristics: 
- MWEPs are of high national or even transnational relevance.

- They exhibit a high degree of complexity, resulting in a high demand in financial and human resources. As a consequence, they may involve major financial obligations or even risks.

- Expert knowledge and highly skilled personnel are needed for the establishment and the operation of MWEPs.

- Various stakeholders and social interest groups are affected by MWEPs. Thus, such projects imply the necessity of a reconciliation of different interests of individuals, groups and the society as a whole, national and international.

- The consequences of these projects are in many cases irreversible, i.e. the initial state of the system (ecological, constructional, social) cannot be restored.

- MWEPs tie up a large amount of resources and, therefore, limit the choice of options for action both for the presence and for the future.

\subsection{Water Technologies - Uses and Functions}

Within the scope of this volume, three main fields of application of water technologies are of particular relevance and will be discussed in the following, comprising:

- Water storage

- Water distribution

- Water use

The main emphasis of the considerations on the effects of water technologies in this context is placed upon the potentially critical and adverse aspects, as these issues tend to be underestimated in many cases and need to be included in comprehensive assessments of MWEPs.

\subsubsection{Water Storage}

One of the major functions of dams, i.e. prominent examples of MWEPs, is to have water in store for purposes at a later point in time. Reservoirs provide water for consumption and irrigation and for the production of energy. Furthermore, dams serve as a means of flood protection. While in the history of European industrialisation, the construction of reservoirs in mountainous regions at the source of larger river basins was an accepted and wide-spread procedure with a potential to stimulate the economic development, such projects are being seen more critical from today's viewpoint - particularly concerning the downstream impacts on ecology and hydrology. Nevertheless, large reservoirs are capable of contributing to the necessary and continuous provision with water and energy. Reservoirs and dams were a means of securing the increasing demands of these resources in many industrialised areas of the world. In this regard, they may open up opportunities in terms of the economic and infrastructural development of urban and rural regions. 
On the other hand, reservoirs comprise a number of economic and ecological drawbacks. For example, by their nature they tend to be situated in remote areas far away from the economic centres, resulting in considerable transport expenditures for infrastructure and pumping. They are likely to exhibit negative effects on the global climate: Methane emissions - a driver of climate change - from large reservoirs can be significant (Lima et al. 2007; Barros et al. 2011). These emissions are due to the rotting of organic matter (e.g. from the vegetation and the soils flooded during the filling phase of the reservoirs) in anaerobic conditions. Furthermore, on the global scale, the water losses from reservoirs via evaporation are even larger than the amounts extracted for human consumption (UNEP 2008) (Fig. 3.1).

Reservoirs are known to have substantial impacts on aquatic biodiversity, mainly by constituting a movement barrier to various organisms, but also because flow regimes and habitat characteristics are changed in a distinct way (Vörösmarty et al. 2010). While upstream the increasing sedimentation caused by dams gradually diminishes the storage capacity of the reservoirs, further downstream the lack of transported sediments leads to the deterioration of the river bed. Consequently, groundwater levels are decreasing and lower sedimentation rates may result in a retreat of the coastal lines at the estuaries.

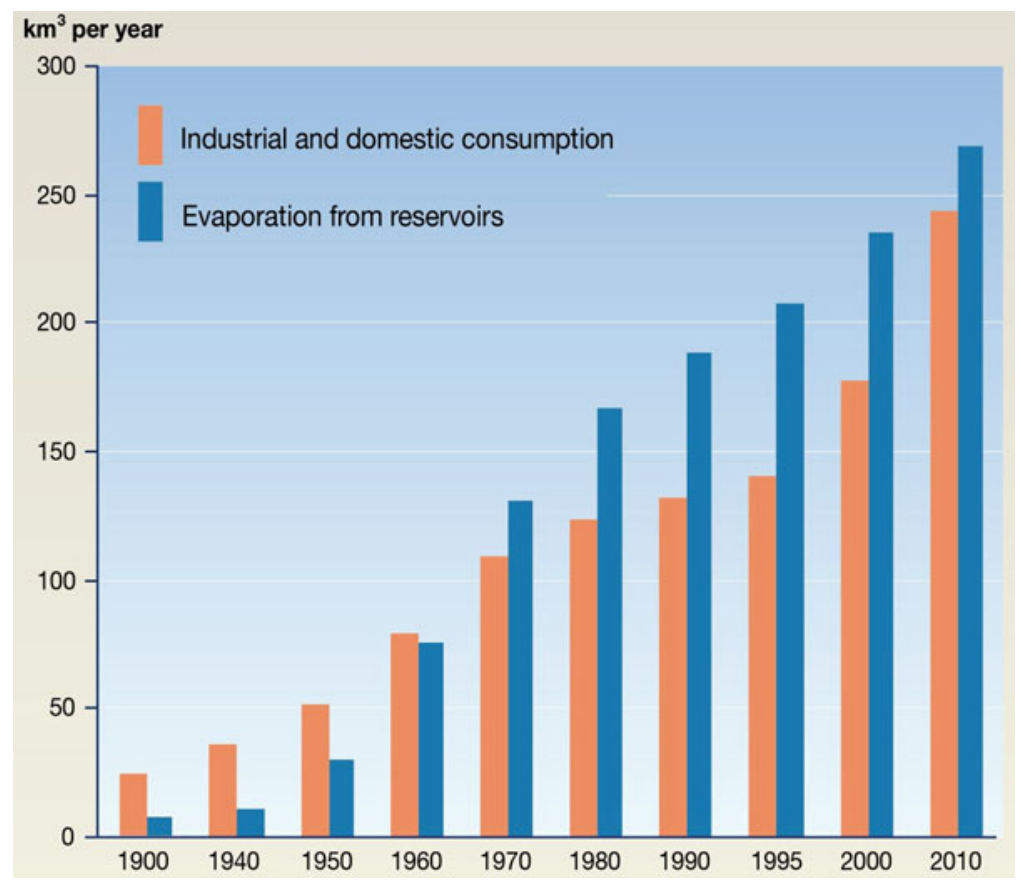

Fig. 3.1 Evaporation from reservoirs compared to global consumption rates of selected sectors. Projections indicate that both global water use and evaporation will continue to increase (Source: Igor A. Shiklomanow, State Hydrological Institute (SHI, St. Petersburg) and United Nations Educational, Scientific and Cultural Organisation (UNESCO, Paris), 1999. Design: Philippe Rekacewicz, http://www.grida.no/graphicslib/) 
Apart from that, sediments serve as natural fertiliser for occasionally flooded arable lands along the rivers. This missing nutrient input has to be compensated by artificial fertilisers. As important humic matter is missing as well, deterioration of the soil quality and its water storage capacity is frequently the consequence. The changes in the groundwater levels around the reservoirs are likely to act as a trigger of soil salinisation.

As can be seen from the description of these potentially adverse effects, largescale water storage facilities also impact on the secondary ways of usage. Along rivers, technical measures and the water withdrawal of upstream resources have implications on the users situated downstream.

Another major criticism against the establishment of dams refers to the fact that during the construction of large reservoirs, considerable amounts of fertile lands are flooded and inhabitants are displaced. Particularly the rights of indigenous populations have been violated in this way, with the compensation measures frequently remaining unsatisfactory (Robinson 2003).

In addition, the proliferation of water-borne diseases like malaria and bilharzia is a problem linked to the construction of large dams and reservoirs, which may pose substantial risks to human health (World Commission on Dams 2000).

\subsubsection{Water Distribution}

The stage that usually follows the storage and collection of water is its distribution to the end users via channels and water pipes. Such transport and distribution systems contribute to improving negative water balances. This is the case not only in dry regions but also in areas exhibiting a humid climate, e.g. when the required water quality cannot be achieved for the amounts needed in densely populated areas. An example is Lake Constance, which supplies a large quantity of the drinking water demand for the federal state of Baden-Wuerttemberg in South Germany. The geographical disconnection of water abstraction and water use over long distances may lead to a detachment of the responsibility for the protection of water resources from the users of the source. The compensation of those regions which provide the service is in many cases not sufficient and not based on objective figures and can thus lead to tensions between the provisioning (rural) areas and the consuming (urban) centres. For dams and reservoirs, this circumstance has been examined by the World Commission on Dams, stating that those who receive the (economic and social) benefits of water distribution infrastructure (such as urban dwellers, farmers and industries) are typically not the same groups that bear the social costs (World Commission on Dams 2000).

Transport of water always implies a certain loss due to leakages and evaporation, especially in open channels. This problem can be studied in a very pronounced way when assessing the water supply of megacities in developing and emerging countries, where about one third of the delivered water volume can be lost via leaky water pipes (Niemczynowicz 1996). Unless natural slopes can be used, the transport over large distances may require considerable amounts of energy - a crucial factor for the determination of the provision costs. This is particularly relevant for the effectiveness of large irrigation systems (this aspect will be dealt with in detail in Part III of this volume). 
Another problematic aspect of large water distribution networks is that the cross-connection of formerly separate water systems can lead to undesired ecological effects and the introduction of non-endemic species into an ecosystem. Manmade waterways (resulting in the interconnection of watersheds) have been mentioned to be among the most important dispersal vectors of invasive aquatic species (Leuven et al 2009).

\subsubsection{Water Use}

In general, societies and individuals use water resources in four major ways. We distinguish between water for human consumption, water for food production purposes, water for industrial uses and water for the generation of (electrical) energy.

On a global scale, $70 \%$ of the freshwater resources are used for agricultural purposes, and only $19 \%$ for industrial and $11 \%$ for domestic purposes (including drinking, washing, food preparation and sanitation) (FAO 2010).

Consequently, water needs to be treated according to the respective intended type of usage. While the water for human consumption purposes requires elaborate treatment technologies, irrigation water in most cases remains untreated and is applied directly to the arable land. Water for industrial processes is treated according to the requirements of the intended usage.

A large proportion of the freshwater resources used by humans are fed into agricultural irrigation systems. These systems can be classified according to their efficiency. A simple definition of the term irrigation efficiency refers to the ratio of the irrigation water consumed by the crops of an irrigation farm or project to the water diverted from a river or other natural water source into the irrigation canal (Jensen 2007). Efficiency varies considerably among different technologies. For example, subsurface micro- or trickle-irrigation in combination with mulch is among the most efficient schemes at present. Nevertheless, the actual efficiency levels highly depend upon the crop water consumption patterns, soil types, cultivation methods and the automation grade (the most technically sophisticated systems use automatised soil moisture measurements in combination with computer-controlled water and fertiliser applications and remote sensing systems).

Large scale irrigation schemes are in many cases installed for the cultivation of so-called "cash crops" (crops for export), while crops for the local needs are in many cases cultivated under rain-fed conditions (an example for this circumstance, the Fergana Valley in Central Asia, is dealt with in detail in Part III of this volume). Cash crops contribute to the "virtual water" balance of nations and regions by binding water in exported crops and thus to increasing the (negative) water balance of the exporting country. "Virtual water trade" is a term used to include the latent/hidden flows of water into water balances, e.g. if food or other products are transferred from one place to another (e.g. Hoekstra and Mekonnen 2012). For example, the consumption of water for livestock farming and the export of meat can be substantial. 
Furthermore, the use of water for environmental needs and environmental services is gaining rising importance (Petts 2009). While formerly the environmental needs of natural ecosystems have not been acknowledged as a factor to be taken into account, today e.g. the protection of wetlands and the ecological restoration of river ecosystems are increasingly gaining attention, particularly in well-developed countries. In order to establish this perspective as an eco-hydrological concept, the term "environmental flows" (or E-flows) has been introduced. An environmental flow is defined as the water regime provided within a river, wetland or coastal zone to maintain ecosystems and their benefits where there are competing water uses and where flows are regulated. It has been argued that water resources need to be managed to provide environmental flows, either by means of modifications of infrastructure or changes in water allocation policies and entitlements (Dyson et al 2003).

\subsection{Principles, Trends and Framework Conditions of Major Water Engineering Projects}

Water technologies have been examined from various perspectives and from different disciplinary angles already. This sub-chapter tries to summarise and condense the findings and experiences made within the scope of major water engineering projects in different parts of the world. Based upon these general observations, we try to formulate general "principles" of such projects. Overarching trends in technology-related water management are defined in order to illustrate the relevance of the topic and the need for interdisciplinary research and assessment approaches. It is important to note that the focus in this regard is on the aspects that tend to be underestimated in many current evaluations and impact assessments of MWEPs. Their undisputedly numerous positive and beneficial effects for economic and social development are usually not as underrepresented as are the uncertainties and risks associated with their implementation.

The statements presented here can be perceived as the conceptual backbone of the practical parts of this volume and as presuppositions and general observations of the previous work of the authors. Furthermore, these principles and trends serve as the basis for an evaluation framework, considering the main compartments of the relevant social, economic and ecological sub-systems that are affected by technological measures of water management. Aspects of this framework will be covered throughout the following chapters of this volume.

- Long-term path dependencies caused by MWEPs may affect the future options for sustainable development of regions and nations.

The provision of water for human needs requires (large-scale) infrastructures, particularly in countries exhibiting a dry and arid climate. In many cases, the type of infrastructure chosen for a specific region determines the availability of further technological options and the remaining radius of action - now and in the future. This 


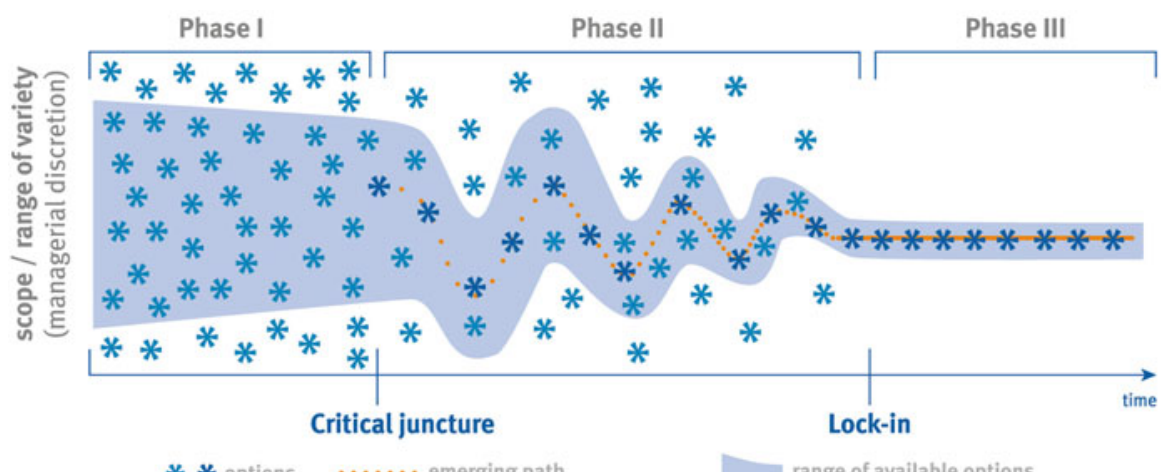

Fig. 3.2 Schematic representation of the emergence of development paths: decisions for particular options limit the future scope of action. The illustration refers to the fact that decisions taken at "critical junctures" reduce the amount of available options for actions of future decisions. After a so-called "lock-in", the present situation can be regarded as irreversible (Source: Altered according to Sydow and Schreyögg (2010, p. 8), previously published in German by Hoechstetter et al. (2013))

circumstance is referred to as "path dependency" (see Fig. 3.2; for details about this concept, refer to Chapter 8 (Moss and Dobner 2015, in this volume, pp. 101-111). For instance, existing waste water collection infrastructures may limit the options for establishing more decentralised waste water treatment installations and minimise the chances to use faecal-free, low-polluted waste water for domestic or industrial purposes after appropriate processing and treatment. This is mainly due to the high investment costs of infrastructure projects and their long period of amortisation. This circumstance is studied by the example of the Red Sea - Dead Sea Conveyance Project in the Middle East (see Part IV of this volume).

- MWEPs have economic consequences for investors and the society; long-term financial commitments connected to MWEPs may constitute a potential burden.

Most water management technologies in MWEPs require specific organisational structures for planning, operation, control and supervision. The costs for setting up and maintaining such structures are underestimated in many cases or simply disregarded as "external costs". That is, costs that have to be carried by third parties and that are not charged via markets. The costs for an effective operation of MWEPs can be considerable. They may have a direct effect on the provision costs of water to the end users. Moreover, they bind financial resources for a long time and thus limit the options for action in the future - thus constituting another source of path dependencies. Studies have suggested that under certain circumstances, waiving of large-scale technical measures (e.g. channels, barriers, dams) in favour of smaller-scale decentralised solutions (e.g. rehabilitation measures) can lead to positive net economic benefits when all external costs are appropriately assessed (Becker et al 2014). According estimations can only be based on an analysis of every individual case. 


\section{- MWEPs potentially have effects on both water quality and water quantity.}

Criteria of water quality and quantity may be directly linked to each other, especially when we look at the usage of surface water: While, on the one hand, quantitative aspects can be solved by an improved management of quality, intelligent management of water amounts can, on the other hand, have positive impacts on water quality. For instance, the use of fertilisers in (irrigation) agriculture or the establishment of closed water cycles in industrial processes may have direct impacts on the water quality. The higher the water quality at the outlet of a process, the larger the amounts of water that are available for the end users. However, the relationship between water quality and quantity is a very complex one, its nature depending strongly on the individual catchment, the type of the aquatic ecosystem under consideration and the socio-economic framework conditions (Australian Government 2013).

\section{- MWEPs are embedded into local and regional framework conditions.}

There is a wide range of technical solutions for different water-related problems, but they are not always adapted to the specific regional needs or capacities. Biochemical treatments of waste water, for instance, have to be adjusted to the specific climatic conditions in order to assure satisfying treatment results. The complexity of technical solutions has an impact on their potential field of application. Local knowledge and capacities as well as issues of long-term maintenance have to be taken into consideration when technological decisions are made. Integrated views and approaches can open up synergies in this regard. For instance, water provision and disposal of waste water may be regarded as interlinked sectors, based on the actual local framework conditions. Attempts to reuse domestic wastewater for diverse purposes, such as for agricultural irrigation, have proven to be successful in many parts of the world already (Oron et al 1999).

- MWEPs are frequently embedded in an international/interstate context; complex legal issues pose a challenge to international water law.

Flowing water does not stop at political borders. Therefore, international aspects are a crucial variable for the implementation of MWEPs. Water law is evolving more and more into a part of environmental law under the leading principle of sustainability (Farrajota 2009). This is true for both national and international law and reflects that rational water law has to be compatible on all levels of regulation. Integrated water resource management (IWRM) incorporates basic elements of modern (European) water law, such as the focus on river basins as management objectives or public participation during the planning and establishment of water management framework plans. In general, there are three largely undisputed rules of customary international water law concerning non-navigational uses of international water resources. These are the rule of equitable and reasonable utilisation, the no-harm rule and the duty to cooperate. Apart from that, the content of framework conventions and regional water treaties forms a heterogeneous legal foundation, on the basis of which interstate conflicts need to be dealt with. 
- Technological solutions for water-related problems may both impede or foster more far-reaching systemic changes of the water sector.

In the short and medium term, technical solutions can provide the desired results for a certain water-related problem. In the long run, however, the focus on a merely technical approach for solving water-related problems can hamper more extensive and sustainable systemic changes, such as modifications in water consumer patterns, changes in agricultural cultivation practices towards a greater climatic adaptability or the introduction of economic incentive instruments. This may be due to the above-mentioned path dependencies. For instance, Libecap (2011) has illustrated how past arrangements to meet conditions of the time have constrained contemporary economic opportunities, using measures implemented in the American West in the late nineteenth and early twentieth centuries and their effect on today's water markets as an example.

- MWEPs can result in external effects that need to be considered.

Water technologies imply external effects, i.e. concern other individuals, groups or societies are affected without being compensated. Examples include a positive or negative carbon footprint or potentially negative and positive effects on the environment. These effects and their financial, social, economic and ethical consequences need to be included in an overall assessment of MWEPs. Most MWEPs tend to be supply-oriented and neglect external effects. However, state intervention regulation or demand-oriented measures like the introduction of water saving devices or pricing policies may turn out to be more sensible when they are compared to the establishment of MWEPs (such as the installation of sea water desalination plants in the case of Israel, Becker 2010).

- MWEPs affect public and private stakeholders on all societal levels.

For a successful implementation of technical solutions, a broad participation and an involvement of the end users in the planning process and beneficiaries throughout all phases of the planning and operation process is likely to have a positive effect. Participation can help to build trust and enhances the cooperation between the users and planners. With concern to an overall project perspective, the early participation of users can help to reduce the costs for implementation and operation. For example, Newig et al. (2005) have shown that the participation of interested parties and the broader public can be an important instrument to both deal with and, where possible, reduce uncertainty associated with the implementation of the European Water Framework Directive (WFD), which involves technological and systemic measures on different societal levels.

\subsection{An Evaluation Framework of MWEPs}

Taking into account the definition and the general principles mentioned above, the complex and far-reaching impact (both desired and undesired) of major water engineering projects becomes obvious. Therefore, transdisciplinary perspectives and 
integrated assessments are needed in order to comprehensively capture the impact of such projects on different societal and ecological sectors and levels. An according "evaluation framework" that covers the main systems and processes involved and that assesses the outcomes of implemented projects is presented here and will be reflected by the course of action in the case studies (Parts III and IV of this volume).

The concept has been inspired by the analytical framework designed for socialecological systems by Ostrom and Cox (2010). Based upon this fundamental work, primary classes of entities have been defined, which are embedded in a social, economic and political setting. The primary elements of this framework (see Table 3.1) are the resource systems and the physical framework conditions, the governance systems, social systems/stakeholder concerns and issues of the operation, management and maintenance of MWEPs. In addition, the "outcomes" or the measurable impact of MWEPs can be assessed along the categories of social, ecological and economic performance. In general, an assessment of all the sectors and compartments mentioned appears to be necessary to secure a successful

Table 3.1 Evaluation framework major water engineering projects

\begin{tabular}{|c|c|c|c|}
\hline \multicolumn{4}{|l|}{ Systems and processes } \\
\hline $\begin{array}{l}\text { Resource systems and } \\
\text { physical framework } \\
\text { conditions }\end{array}$ & Governance systems & $\begin{array}{l}\text { Social systems } \\
\text { and stakeholder } \\
\text { concerns }\end{array}$ & Technology systems \\
\hline $\begin{array}{l}\text { Geographical } \\
\text { attributes and } \\
\text { boundaries }\end{array}$ & Rules and norms & Group attributes & Technological attributes \\
\hline $\begin{array}{l}\text { Existing and } \\
\text { complementary } \\
\text { infrastructure }\end{array}$ & Property right regimes & Leadership & $\begin{array}{l}\text { Achievement of } \\
\text { objectives and goals }\end{array}$ \\
\hline $\begin{array}{l}\text { Economic value of } \\
\text { relevant ecosystem } \\
\text { services }\end{array}$ & Governance mode & $\begin{array}{l}\text { Rules of } \\
\text { participation }\end{array}$ & $\begin{array}{l}\text { Monitoring } \\
\text { (environmental, social, } \\
\text { economic) }\end{array}$ \\
\hline $\begin{array}{l}\text { Productivity and } \\
\text { effectiveness }\end{array}$ & $\begin{array}{l}\text { Monitoring and } \\
\text { sanctioning processes }\end{array}$ & $\begin{array}{l}\text { Capacity and } \\
\text { social capital }\end{array}$ & $\begin{array}{l}\text { Management and } \\
\text { operation }\end{array}$ \\
\hline Resource properties & Participatory processes & $\begin{array}{l}\text { Resource } \\
\text { dependence }\end{array}$ & Human resources \\
\hline $\begin{array}{l}\text { Resource challenges } \\
\text { (e.g. climate and } \\
\text { demographic change) }\end{array}$ & $\begin{array}{l}\text { Network structure } \\
\text { (centrality, } \\
\text { connectivity, number } \\
\text { of levels) }\end{array}$ & $\begin{array}{l}\text { Acceptance of } \\
\text { and familiarity } \\
\text { with technology } \\
\text { used }\end{array}$ & \\
\hline \multicolumn{4}{|l|}{ Outcomes } \\
\hline $\begin{array}{l}\text { Social performance } \\
\text { (e.g. equity, } \\
\text { accountability, } \\
\text { sustainability) }\end{array}$ & $\begin{array}{l}\text { Ecological } \\
\text { performance (e.g. } \\
\text { exploitation, ecosystem } \\
\text { resilience and } \\
\text { resistance, biodiversity, } \\
\text { sustainability) }\end{array}$ & \multicolumn{2}{|c|}{$\begin{array}{l}\text { Economic performance (e.g. efficiency, } \\
\text { cost-recovery, cost-benefit ratio, external } \\
\text { costs) }\end{array}$} \\
\hline
\end{tabular}

Source: In its outline based upon Ostrom and Cox (2010) and Ostrom (2009) 
implementation and operation of water engineering projects and may serve as a general evaluation guideline.

Considering and investigating every aspect of this analytical framework will in many cases go beyond the scope of standard evaluation and monitoring approaches, depending on the size, scope and context-dependency of the project of concern. Therefore, according analyses will have to concentrate on the main relevant subsystems and outcomes applying in specific situations. Nevertheless, we are convinced that general recommendations can be derived if this interpretative and comprehensive framework is applied. Important issues with regard to the volume at hand are the institutional frame settings and the challenges that MWEPs pose to the management of natural resources. Particular emphasis will be on the evaluation and weighing up of the benefits and costs and their distribution among the different stakeholders - e.g. when comparing the implementation of the Red Sea - Dead Sea Conveyance Project in the Middle East and its potential alternatives (see Part IV of this volume).

Open Access This chapter is distributed under the terms of the Creative Commons Attribution Noncommercial License, which permits any noncommercial use, distribution, and reproduction in any medium, provided the original author(s) and source are credited.

\section{References}

Australian Government (2013) Characterising the relationship between water quality and water quantity. Department of Sustainability Environment Water Population and Communities, Canberra

Barros N, Cole JJ, Tranvik LJ et al (2011) Carbon emission from hydroelectric reservoirs linked to reservoir age and latitude. Nat Geosci 4:593-596. doi:10.1038/ngeo1211

Becker N (2010) Desalination and alternative water-shortage mitigation options in Israel: a comparative cost analysis. J Water Res Prot 02:1042-1056. doi:10.4236/jwarp.2010.212124

Becker N, Helgeson J, Katz DL (2014) Once there was a river: a benefit-cost analysis of rehabilitation of the Jordan River. Reg Environ Chang 14:1303-1314. doi:10.1007/s10113-013-0578-4

Dyson M, Bergkamp G, Scanlon J (eds) (2003) Flow - the essentials of environmental flows, 2nd edn. IUCN, Gland

FAO (2010) Aquastat - the FAO's global water information system. Food and Agriculture Organization of the United Nations (FAO). http://www.fao.org/nr/water/aquastat/main/index. stm. Accessed $10 \mathrm{Feb} 2015$

Farrajota MM (2009) International cooperation on water resources. In: Dellapenna JW, Gupta J (eds) The evolution of the law and politics of water. Springer, Dordrecht, pp 337-352

Hoechstetter S, Bens O, Bismuth C (2013) Konflikte um die Georessource Wasser in Zentralasien. System Erde 3:50-55. doi:10.2312/GFZ.syserde.03.02.8

Hoekstra AY, Mekonnen MM (2012) The water footprint of humanity. Proc Natl Acad Sci 109:3232-3237. doi:10.1073/pnas.1109936109

Jensen ME (2007) Beyond irrigation efficiency. Irrig Sci 25:233-245. doi:10.1007/ s00271-007-0060-5

Leuven RSEW, Velde G, Baijens I et al (2009) The River Rhine: a global highway for dispersal of aquatic invasive species. Biol Invasions 11:1989-2008. doi:10.1007/s10530-009-9491-7

Libecap GD (2011) Institutional path dependence in climate adaptation: Coman's "Some unsettled problems of irrigation.”. Am Econ Rev 101:64-80. doi:10.1257/aer.101.1.64 
Lima IBT, Ramos FM, Bambace LAW (2007) Methane emissions from large dams as renewable energy resources: a developing nation perspective. Mitig Adapt Strateg Glob Chang 13:193206. doi:10.1007/s11027-007-9086-5

Lotti C (1980) Water engineering. Water Int 5:18-27. doi:10.1080/02508068008685882

Moss T, Dobner P (2015) Between multiple transformations and systemic path dependencies. In: Huettl RF, Bens O, Bismuth C, Hoechstetter S (eds) Society - water - technology: a critical appraisal of major water engineering projects. Springer, Dordrecht, pp 101-111

Newig J, Pahl-Wostl C, Sigel K (2005) The role of public participation in managing uncertainty in the implementation of the Water Framework Directive. Eur Environ 15:333-343. doi:10.1002/ eet.398

Niemczynowicz J (1996) Megacities from a water perspective. Water Int 21:198-205. doi: $10.1080 / 02508069608686515$

Oron G, Campos C, Gillerman L et al (1999) Wastewater treatment, renovation and reuse for agricultural irrigation in small communities. Agric Water Manag 38:223-234. doi:10.1016/ S0378-3774(98)00066-3

Ostrom E (2009) A general framework for analyzing sustainability of social-ecological systems. Science 325:419-422. doi:10.1126/science.1172133

Ostrom E, Cox M (2010) Moving beyond panaceas: a multi-tiered diagnostic approach for socialecological analysis. Environ Conserv 37:451-463. doi:10.1017/S0376892910000834

Petts GE (2009) Instream flow science for sustainable river management. J Am Water Resour Assoc 45:1071-1086. doi:10.1111/j.1752-1688.2009.00360.x

Robinson WC (2003) Risks and rights: the causes, consequences, and challenges of developmentinduced displacement. The Brookings Institution - SAIS project on internal displacement, Washington, DC

Sydow J, Schreyögg G (2010) Understanding institutional and organizational path dependencies. In: Schreyögg G, Sydow J (eds) The hidden dynamics of path dependence. Institutions and organizations. Palgrave Macmillan, Houndmills/New York, pp 3-12

UNEP (2008) Vital water graphics - an overview of the state of the world's fresh and marine waters. In: Global water policy and strategy, , 2nd edn. http://www.unep.org/dewa/vitalwater/ article32.html. Accessed 10 Feb 2015

Vörösmarty CJ, McIntyre PB, Gessner MO et al (2010) Global threats to human water security and river biodiversity. Nature 467:555-561

World Commission on Dams (2000) Dams and development: a new framework for decisionmaking. Earthscan Publications, London/Sterling 